\title{
The Role of the Jury and the Court in Assessing Front Pay Awards Under the Age Discrimination in Employment Act
}

\author{
Lisa von der Mehden $\dagger$
}

Concerned with the high unemployment rate among older workers and the difficulties faced by older workers seeking "to retain their jobs or to regain employment after being displaced,"1 Congress enacted the Age Discrimination in Employment Act $(\mathrm{ADEA})^{2}$ in 1967. Under the ADEA, victims of age discrimination may seek a variety of remedies. Most commonly, plaintiffs are awarded lost wages or "back pay,"s liquidated damages," and reinstatement.

In recent years, however, courts have increasingly come to recognize that reinstatement is often infeasible, particularly when the employment relationship has been irreparably damaged by the animosity flowing from litigation. ${ }^{5}$ The federal courts have universally recognized that to make the plaintiff whole in such cases it is necessary to award "front pay," a monetary award representing lost future earnings and benefits. ${ }^{6}$ An award of front pay is typically a

† B.A. 1988, The University of California, Berkeley; J.D. Candidate 1992, The University of Chicago.

129 USC \& 621(a) (1988).

2 Age Discrimination in Employment Act of 1967 (ADEA), Pub L No 90-202, 81 Stat 602 (1967), codified with amendments at 29 USC \$§ 621-634 (1988 \& Supp 1990).

" Lost wages, or "back pay," are those wages lost between the date of termination of employment and the date of trial. Cancellier $v$ Federated Dept. Stores, 672 F2d 1312, 1317 n 4 (9th Cir 1982); Dean v American Security Ins. Co., 559 F2d 1036, 1039 n 9 (5th Cir 1977).

4 A doubling of the back pay award in cases of willful violations. See 29 USC $\$ 626(\mathrm{~b})$ (1988). See also HR Conf Rep No 95-950, 95th Cong, 2d Sess 13 (1978), reprinted in 1978 USCCAN 528, 535.

Shittlesey v Union Carbide Corp., 742 F2d 724, 729 (2d Cir 1984); EEOC v Kallir, Philips, Ross, Inc., 420 F Supp 919, 926-27 (S D NY 1976); EEOC v Prudential Federal Sav. \& Loan Ass'n, 763 F2d 1166, 1172 (10th Cir 1985); Cancellier, 672 F2d at 1319. Even where there is tension in the workplace, courts will still award reinstatement if that is what the plaintiff wants. See Spagnuolo v Whirlpool Corp., 641 F2d 1109, 1114-15 (4th Cir 1981) (court affirmed reinstatement award over vigorous objections by the employer that, among other things, "animosities and tensions between the parties made reinstatement infeasible").

- Gibson v Mohawk Rubber Co., 695 F2d 1093, 1100 (8th Cir 1982). The early days of the front pay award were marked by considerable controversy as to its legitimacy and desirability as a remedy. See, for example, Comment, Settling the Front Pay Controversy Under 
lump sum award calculated from the date of judgment to age seventy or to normal retirement age, ${ }^{7}$ adjusted to reflect potential earnings in mitigation of damages, ${ }^{8}$ and discounted to present value. $^{9}$

The courts disagree, however, as to who should calculate the amount of front pay: the judge or the jury. ${ }^{10}$ The ADEA provides generally for trial by jury ${ }^{11}$ but offers little guidance for determining which issues should go to the jury and which should be resolved by the judge. The issue is important to litigants because juries are traditionally more generous than judges. ${ }^{12}$

This Comment addresses the question whether the judge or the jury should determine the proper amount of front pay under the ADEA. The first section outlines the basic statutory background and legislative history of the jury trial provision of the ADEA and reviews the treatment given to this issue by the lower courts. This section demonstrates that Congress intended that the

the Age Discrimination in Employment Act: Whittlesey v. Union Carbide Corp., $59 \mathrm{St}$ John's L Rev 122, 130-32 (1984). See also Note, Front Pay: A Necessary Alternative to Reinstatement under the ADEA, 53 Fordham L Rev 579 (1984). Today virtually all the circuit courts have accepted the front pay award as an available remedy under the ADEA. See Wildman v Lerner Stores Corp., 771 F2d 605, 615-16 (1st Cir 1985); Whittlesey, 742 F2d at 726; Maxfield v Sinclair Int'l, 766 F2d 788, 795-96 (3d Cir 1985); Duke v Uniroyal, Inc., 928 F2d 1413, 1423 (4th Cir 1991); Hansard v Pepsi-Cola Metropolitan Bottling Co., Inc., 865 F2d 1461, 1469 (5th Cir 1989); Fite v First Tennessee Production Credit Ass'n, 861 F2d 884, 892 (6th Cir 1988); McNeil v Economics Laboratory, Inc., 800 F2d 111, 118 (7th Cir 1986); Gibson, 695 F2d at 1100-01; Cancellier, 672 F2d at 1319; Prudential Federal, 763 F2d at 1172; O'Donnell $v$ Georgia Osteopathic Hospital, Inc., 748 F2d 1543, 1551 (11th Cir 1984). See also Thompson v Sawyer, 678 F2d 257, 292-93 (DC Cir 1982) (approving of the front pay award under Title VII).

7 Gibson, $695 \mathrm{~F} 2 \mathrm{~d}$ at $1101 \mathrm{n} 8$.

8 Whittlesey, 742 F2d at 728-29.

- Maxfield, 766 F2d at 797.

${ }^{10}$ Compare Fite, 861 F2d at $892-93$ (amount of front pay. is a jury question); Coston $v$ Plitt Theatres, Inc., 831 F2d 1321, 1333 n 4 (7th Cir 1987) (same), vacated on other grounds, 486 US 1020 (1988); and Maxfield, 766 F2d at 796 (same); with Dominic v Consolidated Edison Company of New York, 822 F2d 1249, 1257-58 (2d Cir 1987) (front pay is matter for the trial judge's "equitable discretion"); Wildman, 771 F2d at 616 (same); and Gibson, 695 F2d at 1100 (same).

1129 USC \& 626(c)(2).

${ }^{12}$ Most plaintiffs' lawyers prefer juries because they believe juries are more likely to award damages out of sympathy if liability is unclear, and because they believe that a jury's assessment of damages is likely to be larger than a judge's. Douglas Laycock, Modern American Remedies: Cases and Materials 353 (Little, Brown, 1985). This belief is supported by anecdotal evidence in cases of remittitur. See, for example, Dominic, 822 F2d at 1253 (district court judge reduced the jury's front pay award from $\$ 378,000$ to $\$ 34,000)$; Doyne v Union Electric Co., 755 F Supp 866, 870-72 (E D Mo 1991) (judge remitted jury's front pay award from $\$ 273,000$ to $\$ 16,000$ ); Farber v Massillon Bd. of Educ., 917 F2d 1391, 1397 (6th Cir 1990) (lower court judge remitted jury's damages award by half), cert denied, $111 \mathrm{~S} \mathrm{Ct}$ 952 (1991). 
jury trial right would extend only to the factual issues surrounding a plaintiff's legal (as opposed to equitable) claims. Section II addresses the question whether front pay is a legal or an equitable remedy by examining the remedies provision of the ADEA and the treatment of the law/equity distinction in case law. In this section, the Comment concludes that the award of front pay is a legal remedy and that, accordingly, the jury should calculate the amount of front pay. Section III demonstrates that pragmatic considerations also support jury assessment of the front pay award.

\section{The Jury Trial Provision}

\section{A. General Statutory Background}

When Congress first enacted the ADEA in 1967, the Act did not refer to the right to a jury trial at all. ${ }^{13}$ This caused confusion among the courts. ${ }^{14}$ The Supreme Court resolved the conflict among the circuits in Lorillard $v$ Pons ${ }^{15}$ holding that a jury trial is available in actions brought under the ADEA.

Following the Supreme Court's decision in Lorillard, Congress amended the ADEA in 1978 to provide explicitly for jury trials. The resulting provision, $\S 7(\mathrm{c})(2)$, states:

In an action brought [in a court of competent jurisdiction], a person shall be entitled to a trial by jury of any issue of fact in any such action for recovery of amounts owing as a result of a violation of this chapter, regardless of whether equitable relief is sought by any party in such action. ${ }^{16}$

As at least one court has pointed out, this language is subject to conflicting interpretations: either all factual issues are to be tried to a jury, or only those facts relating to a plaintiff's legal claims are to be tried to a jury. ${ }^{17}$

When stripped of its clarifying and descriptive clauses, the provision's general statement is that there is a right to a jury trial for "any issue of fact" in "any such action." At face value, this language seems to require that the court focus on whether an issue is factual, not on whether it is legal or equitable. Thus, if an issue

1s See ADEA of 1967, 81 Stat 602 (cited in note 2).

14 See, for example, Morelock v NCR Corp., 546 F2d 682, 689 (6th Cir 1976) (no right to jury trial); and Rogers v Exxon Research and Engineering Co., 550 F2d 834, 839 (3d Cir 1977) (right to jury trial).

${ }^{16} 434$ US 575 (1978).

16 29 USC \& 626(c)(2).

17 Dominic, 822 F2d at 1257. 
is deemed to be factual, the provision compels a jury trial. Under this approach, the amount of front pay necessary to compensate the plaintiff would be a factual issue requiring jury determination. $^{18}$

However, this interpretation proves too much. Requiring the court to submit all factual issues to the jury effectively robs the judge of her traditional role in determining and awarding equitable remedies. Even clearly equitable remedies, such as judgments compelling reinstatement, involve factual questions. ${ }^{19}$

A better interpretation, one which is generally accepted by the federal courts, is that the jury is to decide only those facts relating to the plaintiff's legal claims. ${ }^{20}$ This interpretation may be inferred from the language and structure of $\S 7$ (c), which provides that the right to a jury trial is not to be hindered if a party also seeks equitable relief. The congressional authors seem to have assumed that the traditional distinction between legal claims and equitable claims also applied to the ADEA because they contrasted "equitable relief" with claims in which there is a "trial by jury."21

That Congress intended to preserve the traditional legal/equitable distinction is also supported by statements made in the House Conference Report accompanying the 1978 amendments. In the context of discussing the right to jury trial as it applied to claims for liquidated damages, the House Conference Report placed great emphasis on the "legal" nature of liquidated damages, and concluded from that fact alone that jury trials-were appropriate. ${ }^{22}$ The Conference Report made no mention of front pay awards, perhaps because at that time front pay was not yet recognized as an available remedy ${ }^{23}$ However, it seems Congress would

18 Id (plaintiff "argue[d] that once the trial judge has found an award of front pay to be appropriate, the amount reasonably necessary to compensate the plaintiff is a factual issue that must be submitted to the jury under the ADEA").

10 See J. Hardin Marion, Legal and Equitable Remedies Under the Age Discrimination in Employment Act, 45 Md L Rev 298, 326, 328 (1986).

${ }^{20}$ Dominic, $822 \mathrm{~F} 2 \mathrm{~d}$ at 1257 ("Our analysis of the structure of Section 626 indicates that Congress intended to limit jury trials to factual issues underlying claims for legal relief."); Deloach v Delchamps, Inc., 897 F2d 815, 824 n 5 (5th Cir 1990) ("[T] intended to provide jury trial rights on claims considered legal in nature."). See generally, Marion, $45 \mathrm{Md}$ L Rev 298 (cited in note 19).

${ }_{21}$ Dominic, 822 F2d at 1257 ("There is no evidence [in the legislative history of $\S 7(c)(2)]$ that Congress intended to depart from the traditional distinctions between legal and equitable claims embodied in the seventh amendment.").

${ }_{22}$ HR Conf Rep No 95-950 at 13-14 (cited in note 4) stated, "[b]ecause liquidated damages are in the nature of legal relief, it is manifest that a party is entitled to have the factual issues underlying such a claim decided by a jury."

${ }^{23}$ Front pay was not routinely awarded under the ADEA until the early 1980s. As an example of an early case, see Gibson, 695 F2d at 1100 (allowing "monetary damages in lieu of reinstatement"). 
have assumed that the right to a jury trial for the assessment of the front pay award should also hinge upon its classification as either a legal or an equitable form of relief.

\section{B. Lower Courts' Treatment of the Issue}

The circuit courts generally agree that when the plaintiff prays for a jury trial in an ADEA suit, the jury hears and determines the legal issues and assesses legal damages, but the court determines equitable issues and awards equitable relief. ${ }^{24}$ Under this interpretation, if front pay is a form of legal relief, then the jury should determine the factual issues underlying the award of front pay and the amount of any award. The circuit courts are divided, however, on the question of whether the front pay award is legal or equitable. Neither side engages in rigorous analysis of the issue. For example, in Fite $v$ First Tennessee Production Credit Ass'n, the Sixth Circuit handled the issue by stating only that the contention that front pay is not a question for the jury is "at odds with the authority of this circuit." Similarly, in Coston v Plitt Theatres, Inc., the Seventh Circuit buried its conclusion in dicta in a footnote: "Authority and reason both suggest that while the decision to award front pay is within the discretion of the trial court, the amount of damages available is a jury question." 26

Courts that have held that assessment of front pay is an issue for the judge are equally conclusory. The Eighth Circuit in Gibson $v$ Mohawk Rubber Co., for example, merely stated that "[t]he equitable relief that the district court may grant includes ... monetary damages in lieu of reinstatement."27 In Wildman v Lerner Stores Corp., the First Circuit stated that because the trial judge awards reinstatement, she should also calculate front pay. ${ }^{28}$ In Dominic $v$ Consolidated Edison Company of New York, the court simply assumed from the beginning that front pay was an equitable remedy, and that therefore the assessment of the award was within the dis-

36 Id; Dickerson v Deluxe Check Printers, Inc., 703 F2d 276, 279-80 \& n 2 (8th Cir 1983); Loeb v Textron, Inc., 600 F2d 1003, 1022 n 33 (1st Cir 1979). See Marion, 45 Md L Rev 298 (cited in note 19).

${ }^{25} 861$ F2d 884, 893 (6th Cir 1988), citing Davis v Combustion Engineering, Inc., 742 F2d 916, 923 (6th Cir 1984).

26 831 F2d 1321, 1333 n 4 (7th Cir 1987), vacated on other grounds, 486 US 1020 (1988).

27 695 F2d 1093, 1096 (8th Cir 1982).

2s 771 F2d 605, 616 (1st Cir 1985). 
cretion of the trial judge. ${ }^{29}$ More recently, in Deloach $v$ Delchamps, Inc., the Fifth Circuit concluded that front pay is an equitable remedy because it is awarded in lieu of the equitable remedy of reinstatement. ${ }^{30}$ To date, no court has conducted a thorough, careful analysis of whether front pay is a legal or an equitable remedy.

\section{Front Pay: A Legal or an Equitable Remedy?}

The availability of a right to a jury trial under the ADEA depends upon the legal or equitable nature of the particular claim. This section will address the question of whether front pay is legal or equitable by examining first, the remedies provision of the ADEA and second, common law cases dealing with the traditional legal/equitable distinction.

\section{A. The ADEA's Remedies Provision}

The ADEA's remedies provision, $\S 7(\mathrm{~b}),{ }^{31}$ provides for two categories of relief. The first is "amounts owing . . . as a result of a violation"; the second is "such legal or equitable relief as may be appropriate to effectuate the purposes" of the Act.

\section{Amounts owing.}

The first category, "amounts owing to a person as a result of a violation," is legal relief. The language of the provision states that such "amounts owing" are to be treated as "unpaid minimum wages or unpaid overtime compensation for the purposes of [the Fair Labor Standards Act]." 32 Congress inserted this reference to ensure that claims brought under the ADEA would receive the same treatment as claims brought under the FLSA. The Supreme

30 822 F2d 1249, 1257 (2d Cir 1987).

so 897 F2d 815, 824 (5th Cir 1990).

s1 Section 7(b) states in relevant part that:

Amounts owing to a person as a result of a violation of this chapter shall be deemed to be unpaid minimum wages or unpaid overtime compensation for purposes of [the Fair Labor Standards Act]: Provided, That liquidated damages shall be payable only in cases of willful violations of this chapter. In any action brought to enforce this chapter the court shall have jurisdiction to grant such legal or equitable relief as may be appropriate to effectuate the purposes of this chapter, including without limitation judgments compelling employment, reinstatement or promotion, or enforcing the liability for amounts deemed to be unpaid minimum wages or overtime compensation under this section.

29 USC § 626(b).

${ }^{32}$ Id. 
Court in Lorillard stated that Congress intended that the jury trial right, which is available in FLSA cases for "unpaid minimum wages or unpaid overtime compensation," also be available in ADEA actions for "amounts owing"-those that are treated as "unpaid minimum wages or unpaid overtime compensation" under the FLSA. ${ }^{33}$

Although the ADEA does not define the types of remedies encompassed by $\S 7(\mathrm{~b})$ 's term "amounts owing," the accompanying House Conference Report stated that it "includes items of pecuniary or economic loss such as wages, fringe benefits, and other jobrelated benefits, as well as liquidated damages for nonpecuniary losses arising out of a willful violation." ${ }^{34}$ Although Lorillard referred only to lost wages, not to liquidated damages, ${ }^{35}$ the Conference Report concluded that "because liquidated damages are in the nature of legal relief, it is manifest that a party is entitled to have the factual issues underlying such a claim decided by the jury.",36

Thus, if front pay were classified as an "amount owing," the inquiry could end here. Is front pay, then, an "amount owing?" It seems counterintuitive to say that it is not, since by any definition it represents pecuniary loss. And, since front pay represents wages denied to a victim due to wrongful termination, it is as much an "amount owing" as back pay is.

The common law did not distinguish between the remedies of back pay and front pay. In the early history of employment law in the United States, a plaintiff seeking damages for wrongful discharge was entitled to recover the earnings which would have accrued to him for the full term of the contract..$^{37}$ The wrongful discharge was considered a breach of the contract, and the employee was allowed to recover all damages, including past unpaid wages and future wages. Even in cases of employment for long terms or for life, the plaintiff could recover future wages for the remainder of the term of employment. ${ }^{38}$ Thus, at early common law, there was no meaningful distinction between wages owing between the time of the discharge and the trial (the modern notion of "back

33 Lorillard, 434 US at 582-83.

26 HR Conf Rep No 95-950 at 13-14 (cited in note 4).

${ }^{26}$ Lorillard, 434 US at 578-79. See HR Conf Rep No 95-950 at 14 (cited in note 4).

${ }^{36}$ HR Conf Rep No 95-950 at 13-14 (cited in note 4).

37 Pierce v Tennessee Coal, Iron \& Railroad Co., 173 US 1 (1899).

s8 See, for example, Pierce, 173 US 1; Cutter v Gillette, 163 Mass 95, 97, 39 NE 1010 (1895). See generally, Charles T. McCormick, Handbook on the Law of Damages § 161 at 631-32 (West, 1935). 
pay") and wages owing thereafter (the modern notion of "front pay"). The "amount owing" was the total net earnings which would have accrued to the employee under the contract but for the breach, a sum representing both front pay and back pay. ${ }^{38}$ Traditionally, then, the "amount owing" to a plaintiff for wrongful dismissal included a front pay component.

No court, however, has treated front pay as an "amount owing" under the ADEA. ${ }^{40}$ Instead, courts have strictly construed the terms "amounts owing" and "lost wages" to mean only "lost back pay"-that is, wages owing between the time of the violation and the trial. ${ }^{41}$

2. Legal or equitable relief appropriate to effectuate the purposes of the Act.

Ultimately, it is not critical that front pay is an "amount owing," because the ADEA also broadly provides for "such legal or equitable relief as may be appropriate to effectuate the purposes" of the Act. ${ }^{42}$ Every court that has discussed the front pay remedy has treated it as falling within this second category of relief. ${ }^{43}$ The statute lists as examples of "such legal or equitable relief as may be appropriate," judgments compelling employment, reinstatement

s9 This amount was subject to reduction by the amounts that the plaintiff would have been able to earn in other employment in the exercise of ordinary diligence. Galveston $H$. \& S.A. Ry. Co. $v$ Eubanks, 42 SW2d 475, 479 (Tex Civ App 1931). If the employment had a long term to run, deductions were made for the uncertainty of future earnings in view of the uncertainty of the employee's or the employer's death. Hollwedel $v$ Duffy-Mott Co., Inc., 263 NY 95, 105, 188 NE 266, 269 (1933).

${ }^{10}$ In deciding whether to award front pay under Title VII, Judge Posner recently pointed out that the front pay award is really a legal damages award for lost future earnings: "The logic of [awarding front pay], if the purpose of Title VII's remedial scheme is indeed to make the plaintiff whole, is undeniable. But the premise can be doubted, as can the propriety, under a statute confined to equitable relief, of an award of what is realistically damages for lost future earnings-a legal rather than an equitable remedy." McKnight $v$ General Motors Corp., 908 F2d 104, 116-17 (7th Cir 1990) (citations omitted), cert denied, 111 S Ct 1306 (1991).

${ }^{11}$ Dean v American Security Ins. Co., 559 F2d 1036, 1039 n 9 (5th Cir 1977); Cancellier, 672 F2d at 1317 n 4; Kelly v American Standard, Inc., 640 F2d 974, 978 (9th Cir 1981).

12 29 USC \& 626(b).

4s Dominic, 822 F2d at 1258-59; Deloach, 897 F2d at 824 n 5; Prudential Federal, 763 F2d at 1171-72; Whittlesey, 742 F2d at 727-28; Maxfield, 766 F2d at 795-96; Davis v Combustion Engineering, Inc., 742 F2d 916, 922-23 (6th Cir 1984); Bailey v Container Corp. of America, 660 F Supp 1048, 1053 (S D Ohio 1986); Cooper v Asplundh Tree Expert Co., 836 F2d 1544, 1577 (10th Cir 1988) ("The authority to grant front pay as a remedy stems not from the amounts owing language but from the additional power to grant legal and equitable relief."). 
or promotion, or enforcing liability for amounts owing. ${ }^{44}$ The statute does not specify which of these enumerated items of relief are legal and which are equitable. The Supreme Court in Lorillard assumed that Congress knew the significance of the term "legal," and thus reasoned that because judgments compelling "employment, reinstatement or promotion" are clearly equitable, Congress must have included the example of "judgments enforcing liability for amounts owing" as illustrative of legal relief.45

One judge has erroneously concluded from a reading of Lorillard that in order for a remedy to be classified as legal relief under the ADEA, it must fall within the meaning of "amounts owing." However, such an interpretation ignores the fact that the list of legal and equitable remedies is not an exhaustive one. Quite to the contrary, "the types of relief spelled out in the Act" are "exemplary only." "The more accurate reading of Lorillard is that "amounts owing" is one example of legal relief, not that a remedy must be an "amount owing" in order to be considered legal relief. Since the category of relief provided by $\S 7(\mathrm{~b})$ is explicitly "without limitation," 48 presumably any new or supplementary remedy may be added to the list.

In practice, courts have readily adopted this construction. For example, several courts have viewed the phrase "such legal or equitable relief as may be appropriate" as providing an opportunity to award damages for pain and suffering (legal relief), and for compensating ADEA victims for the psychological effects of discrimination (legal relief). ${ }^{49}$ Other courts have looked to this provision as authorizing an award of pre-judgment interest (equitable relief)..$^{50}$

When courts have declined to expand remedies, they have not done so out of a belief that the statute does not allow for unenumerated remedies. Rather, the courts have been restrained

429 USC \& 626(b).

45 Lorillard, 434 US at 583.

16 Blim v Western Electric Co., Inc., 731 F2d 1473 (10th Cir 1984) (Seth dissenting).

${ }^{47}$ Marion, $45 \mathrm{Md}$ L Rev at 302 (cited in note 19).

4. 29 USC \$ 626(b).

40 See Wise v Olan Mills Inc. of Texas, 485 F Supp 542, 543-44 (D Colo 1980); Gifford v B.D. Diagnostics, 458 F Supp 462, 464 (N D Ohio 1978).

so Cline v Roadway Express, Inc., 689 F2d 481, 489 (4th Cir 1982); Kelly v American Standard, Inc., 640 F2d 974, 982 n 13 (9th Cir 1981). Most courts have treated an award of pre-judgment interest as an equitable remedy. The remedy is awarded only in "exceptional circumstances," such as when the jury's liquidated damages award is less than the interest that would have been due from the date the claim for back pay accrued. See Gibson, 695 F2d at 1100-01; Heiar v Crawford County, 746 F2d 1190, 1202 (7th Cir 1984). In those cases where pre-judgment interest has been awarded, a judge has always fashioned the award. 
by other circumstances. For example, most courts have felt that they must follow the practice of the FLSA and not allow pre-judgment interest when liquidated damages are awarded..$^{51}$ Similarly, courts have denied damages for pain and suffering on the ground that such a remedy was inconsistent with the Act's goal of putting plaintiffs in the economic position they would have occupied but for the discrimination, ${ }^{52}$ and because such a remedy might impair the EEOC's mediation and conciliation efforts. ${ }^{53}$ In summary, when courts have limited the availability of remedies under the ADEA, they have done so based on authority outside of the statute's language, since the wording of the statute does not itself limit the relief available. The statute provides for a broad category of legal and equitable relief; it is not necessary that front pay be an "amount owing" for it to be classified as legal relief.

\section{B. The Common Law Approach}

Historically, federal district courts exercised both legal and equitable powers. Although administered by the same judges, these powers were considered separate and distinct. A case could be brought to federal court in law or in equity, but could not proceed in both. This dual system remained intact in the federal courts until 1938 when the adoption of the Federal Rules of Civil Procedure merged the two systems. ${ }^{54}$ Despite the merger, the law/equity distinction is still relevant in determining whether the judge or jury awards a particular remedy. ${ }^{55}$ Unfortunately, few rules exist to inform a distinction between legal and equitable remedies. As a general rule, compensatory and other monetary damages are legal remedies, ${ }^{56}$ while injunctions and specific performance decrees are equitable remedies. ${ }^{57}$ The appropriate categorization of other rem-

s1 Blim, 731 F2d at 1479; Kolb v Goldring, 694 F2d 869, 875 (1st Cir 1982); Cline, 689 F2d at 489.

${ }^{32}$ Kolb, $694 \mathrm{~F} 2 \mathrm{~d}$ at 872.

ss Pfeiffer v Essex Wire Corp., 682 F2d 684, 686-88 (7th Cir 1982); Dean, 559 F2d at 1038-40.

s4 FRCP 2 ("There shall be one form of action to be known as 'civil action.' "). See also Laycock, Modern American Remedies at 335 (cited in note 12).

ss The law/equity distinction also has a constitutional dimension. Specifically, the Seventh Amendment secures the right to jury trial "in suits at common law" as opposed to suits in equity. US Const, Amend VII. See James Fleming, Jr., Right to a Jury Trial in Civil Actions, 72 Yale L J 655 (1963). Because the ADEA itself provides for a jury trial, however, the constitutional inquiry is unnecessary.

${ }^{\text {s8 }}$ Chauffeurs, Teamsters \& Helpers Local No. 391 v Terry, 110 S Ct 1339, 1347-48 (1990); Curtis v Loether, 415 US 189, 196 (1974).

${ }^{37}$ Laycock, Modern American Remedies at 5 (cited in note 12); G.H. Treitel, The Law of Contract 617 (Stevens \& Sons, 4th ed 1975); Dan B. Dobbs, Handbook on the Law of Remedies $\$ 1.1$ at 3 (West, 1973). 
edies, however, is less clear. Restitution is especially murky, with some restitutionary remedies classified as legal, others as equitable. $^{.8}$

This section examines how remedies were classified as legal or equitable at common law. It begins by tracing the historical roots of the front pay remedy, noting that the remedy generally was included in the legal award of compensatory damages given to wrongfully terminated employees. Next, this section considers the presumption that monetary judgments are legal remedies, and then examines the exceptions to this rule: "equitable restitution" and remedies "incidental" to equitable relief. This section concludes that the front pay remedy does not fall within these exceptions and is therefore properly characterized as a legal remedy. Finally, this section addresses and rejects the argument that front pay might be equitable because it is offered in lieu of reinstatement.

\section{Historical analysis.}

One time-honored method of distinguishing between legal and equitable remedies is to conduct an historical analysis. ${ }^{58}$ The historical analysis looks to custom before the merger of law and equity and asks whether a court of law or a court of equity would have awarded the particular remedy.

Back pay was historically a legal remedy. In fact, the First Circuit has described an ADEA action as identical to a common law suit for back wages for breach of contract. ${ }^{60}$ The Third Circuit has stated that "[a] suit for damages consisting of back wages arising out of the breach of an employment agreement is a routine contract action where the parties would be entitled to a jury."

At common law, front pay was also a legal remedy. As was previously noted, ${ }^{62}$ the common law did not make any meaningful distinction between past damages and future damages. Actions for damages for breach of an employment contract typically contained

ss Dobbs, Handbook on the Law of Remedies $\$ 1.1$ at 3 (cited in note 57).

so The Supreme Court currently uses an historical test when determining whether in a given case a jury trial is constitutionally compelled. See, for example, Granfinanciera, S.A. $v$ Nordberg, 492 US 33 (1989); Tull v United States, 481 US 412, 417 (1987).

-o Kolb, 694 F2d at 872.

22 Rogers, 550 F2d at 838.

-2 See notes 43-45 and accompanying text. 
both front pay and back pay components. ${ }^{63}$ Even though the front pay component compensated for a future harm, it was considered legal relief, and juries calculated the amount of the award..$^{64}$

\section{Monetary judgments.}

Not only was front pay historically a legal remedy, but the presumption still exists today that an award of monetary damages is legal relief. In Dairy Queen v Wood, for example, the plaintiff sought an accounting for profits, traditionally equitable relief. ${ }^{65}$ However, the Court emphasized instead that the remedy took the form of a monetary judgment, and for that reason held that it was legal relief. ${ }^{86}$ In Ross $v$ Bernhard, the Court again emphasized that money judgments are legal remedies. ${ }^{67}$ The Court's most recent cases have also expressly applied this presumption. ${ }^{68}$

a) Equitable restitution. Despite the presumption that monetary damages are legal in nature, the Supreme Court has acknowledged that money damages may be "equitable where they are restitutionary." 69 Restitutionary awards differ from damage awards in that restitution does not compensate the plaintiff for losses incurred as a result of the defendant's wrong. Rather, restitution is designed to prevent the unjust enrichment of the defendant and thus it measures the award by the defendant's gain, not by the plaintiff's loss. ${ }^{20}$ Consider, for example, an employer who

8s Doherty v Schipper \& Block, 250 Ill 128, 134, 95 NE 74, 75 (1911); McMullen v Dickinson Co., 60 Minn 156, 62 NW 120, 121 (1895); Howard v Daly, 61 NY 362 (1875).

*4 Hollwedel v Duffy-Mott Co., 238 AD 468, 264 NYS 745, 747 (NY App Div), modified, 263 NY 95, 188 NE 266 (1933) (The measure of damages in a wrongful discharge suit was the "total amount" of all wages "accruing after the breach which the plaintiff, in the opinion of the jury would have lived to earn, subject to all proved diminutions.").

Bs 369 US 469, 476 (1962). See also James W. Moore, Jo Desha Lucas \& Jeremy C. Wicker, Moore's Federal Practice I] 38.25 (Matthew Bender, 2d ed 1988).

1 Dairy Queen, 369 US at 476-77.

67 396 US 531, 542 (1970) ("In the instant case we have no doubt that the corporation's claim is, at least in part, a legal one. The relief sought is money damages.").

${ }^{68}$ See Terry, $110 \mathrm{~S}$ Ct at 1348 ("Generally an action for monetary damages was "the traditional form of relief offered in the courts of law.' "), quoting Curtis, 415 US at 196; Granfinanciera, 492 US at 48 ("where an action is simply for the recovery ... of a money judgment, the action is one at law"), quoting Whitehead $v$ Shattuck, 138 US 146, 151 (1891).

${ }^{60}$ Terry, $110 \mathrm{~S} \mathrm{Ct}$ at 1348. See also Curtis, 415 US at 197 (noting that back pay may be considered a form of restitution in some instances); Porter $v$ Warner Holding Co., 328 US 395,402 (1946) (noting that an award of money granted as restitution for excess rental payments "differs greatly" from an award of monetary damages).

${ }^{70}$ Beesley $v$ Hartford Fire Ins. Co., 723 F Supp 635, 644 (N D Ala 1989); Dobbs, Handbook of the Law of Remedies $\S 1.1$ at 1-2 (cited in note 57); Laycock, Modern American Remedies at 462 (cited in note 12). 
had agreed to give an employee a year-end bonus, but instead kept the money for himself and invested it in stock. If the stock did well, the employee might sue in restitution and recover not only the amount of the bonus but also any appreciation in value realized by the employer, even if the employee would not have invested the money himself. The goal is not to compensate the employee, but to prevent the employer from profiting from his misconduct. ${ }^{71}$

Front pay is a different type of remedy from that described in the previous example. Under the ADEA, a plaintiff typically seeks front pay because he was wrongfully denied, or wrongfully terminated from, a position. In one sense the definition of restitution appears to fit, because the employer may have saved the employee's wages by firing him and that savings may be characterized as an unjust gain. However, the employer probably has not "profited" in most cases, because she will often have to pay those "savings" to a replacement employee. Moreover, by definition, the theory of restitution requires that the defendant have received a benefit bestowed by the plaintiff. ${ }^{72}$ The ADEA plaintiff has not conferred any such benefit upon the employer; a victim of age discrimination does not seek compensation for work already performed (or any other benefits conferred), but for the recovery of what he would have earned but for the employer's discriminatory conduct. Front pay protects the plaintiff's expectation interest and is more akin to damages for breach of contract than it is to restitution.

The Supreme Court has consistently defined restitution in this fashion. In Porter $v$ Warner Holding Co., ${ }^{73}$ the government brought suit against a landlord for charging rents above the amounts prescribed by regulations issued under the Emergency Price Control Act of 1942. ${ }^{74}$ The Act contained a provision allowing the Price Administrator to sue for restitution of amounts unlawfully charged to consumers. The Act also contained a provision al-

71 Justice Cardozo once described the test for restitution as whether a benefit "was received in such circumstances that the possessor will give offense to equity and good conscience if permitted to retain it." Atlantic Coast Line Railroad Co. v Florida, 295 US 301, 309 (1935).

${ }_{72}$ Martin H. Redish, Seventh Amendment Right to Jury Trial: A Study in the Irrationality of Rational Decision Making, 70 N U L Rev 486, 528 (1975) (" 'Restitution' implies that the defendant has been unjustly enriched by receiving some benefit from the plaintiff without providing adequate compensation.").

73328 US 395 (1946).

3456 Stat 23, 33, 50 App USC \& 925(a) (1988) (omitted as terminated). 
lowing a plaintiff to sue for damages, a remedy described as "a remedy at law to persons damaged by having had to pay unlawfully high prices." 78 The Court emphasized that the restitution claim "differs greatly" from the claim for monetary damages, ${ }^{76}$ and that when the government seeks restitution it is not requesting that the court award damages to the consumer. Rather, it is asking the court "to act in the public interest by restoring the status quo and ordering the return of that which rightfully belongs to the [consumer]." "77

More recently, in Terry, the Supreme Court held that the restitution theory did not apply in a case where the plaintiffs sought back pay for their union's breach of the duty of fair representation. The Court stated:

The backpay [sic] sought by respondents is not money wrongfully held by the Union, but wages and benefits they would have received [from the employer] had the Union processed the employees' grievances properly. Such relief is not restitutionary..$^{78}$

Under the Supreme Court's definition, then, front pay would not be classified as restitutionary either.

Even if front pay could somehow be classified as restitutionary, it does not follow that it would necessarily be an equitable remedy. Historically, restitution could be sought both in law and in equity. ${ }^{79}$ Specifically, claims of unjust enrichment and other relief we now regard as restitutionary were available in the English common law courts as assumpsit actions. ${ }^{80}$ Moreover, our common law system has always recognized that the remedy of restitution can take both legal and equitable forms. The Restatement of Restitution specifies that "[i]n situations in which a person is entitled to restitution, he is entitled, in an appropriate case, to one or more of the following remedies: ... a judgment at law or a decree in equity for the payment of money." ${ }^{11}$ Thus, a formalistic attempt to end the inquiry by invoking the label "restitution" is without merit.

7s Porter, 328 US at 402.

76 Id.

77 Id.

28 Terry, 110 S Ct at 1348.

${ }^{79}$ First National Bank v Warren, 796 F2d 999, 1000 (7th Cir 1986) ("remedies known as 'restitution' were available in courts of law and equity alike").

so Gaines $v$ Miller, 111 US 395, 397-98 (1884); Restatement of Restitution, Introductory Note at 5-7, 9-10 (1937).

81 Restatement of Restitution $\$ 4$ at 17-18 (cited in note 80 ). 
b) Remedies "incidental" to equitable relief. The Supreme Court has recognized that historically, courts in equity could award monetary relief that was "incidental to or intertwined with injunctive relief." 82 One might argue that front pay is "incidental" to the equitable remedy of reinstatement, and is therefore itself an equitable remedy. The terms "incidental to" and "intertwined with" refer to an equity court's historical discretion to decide incidental legal claims: by allowing a court in equity to decide claims "incidental" to the equitable relief sought, a plaintiff was able to obtain complete relief without having to bring the legal claims separately in a court of law. This practice was called the "equitable clean-up doctrine." ${ }^{\text {s3 }}$ However, with the merger of the systems of law and equity, the equitable clean-up doctrine became superfluous, since parties could now assert both legal and equitable claims in one forum.

The Supreme Court in Beacon Theatres, Inc. $v$ Westover, ${ }^{84}$ explicitly rejected the notion of incidental legal claims. In Beacon Theatres, the plaintiff sought equitable relief and the defendant counterclaimed seeking legal relief. The lower courts applied the equitable clean-up doctrine to deny the defendant's request for a jury trial on the legal claim. ${ }^{85}$ The Supreme Court reversed, noting that the merger of law and equity gave the parties an adequate remedy at law, and thus there was no longer a valid justification for equity having jurisdiction over "incidental" legal claims. ${ }^{86}$

In Dairy Queen, Inc. $v$ Wood ${ }^{87}$ the Court again explicitly rejected the idea of incidental legal claims. In Dairy Queen, the plaintiff sought an "accounting for profits" and various injunctions for an alleged breach of contract. The district court denied the defendant's demand for a jury trial, claiming that the legal issues were incidental to the equitable nature of the case. ${ }^{88}$ The Supreme Court reversed, explaining that Beacon Theatres held that when legal and equitable issues are presented in a single case the right to

82 Tull v United States, 481 US 412, 424 (1987); Terry, $110 \mathrm{~S} \mathrm{Ct}$ at 1348. See also Mitchell v DeMario Jewelry, Inc., 361 US 288, $291-92$ (1960) (relying on "the historic power of equity to provide complete relief" to justify an injunctive order to an employer to reimburse employees who had been wrongfully discharged).

ss See generally A. Leo Levin, Equitable Clean-up and the Jury: A Suggested Orientation, $100 \mathrm{U}$ Pa L Rev 320 (1951).

${ }^{\circ 4} 359$ US 500 (1959).

85 Id at 503.

86 Id at 508-09.

87 369 US 469 (1962).

" Id at 470 . 
jury trial on the legal issues remains intact. ${ }^{89}$ The Court dismissed outright the view that the jury trial right may be lost by characterizing the legal issues as "incidental" to the equitable issues."

Despite Beacon Theatres and Dairy Queen, some Supreme Court opinions opaquely suggest that there may still be "incidental" legal claims and that the equitable clean-up doctrine still exists. In Terry, for example, the Court stated that "a monetary award 'incidental to or intertwined with injunctive relief' may be equitable." However, without further discussion the Court concluded that "this characteristic is clearly absent from this case." Although the Court ultimately found that the remedies were not intertwined, its acknowledgement that a legal remedy could be intertwined with an equitable remedy stands in direct contrast to its decisions in Beacon Theatres and Dairy Queen.

In Tull $v$ United States, ${ }^{93}$ the Supreme Court considered whether the Seventh Amendment guaranteed the right to trial by jury in an action by the United States government to collect civil penalties and injunctive relief for a violation of the Clean Water Act (CWA). ${ }^{94}$ In the course of examining whether the CWA's civil penalties were legal or equitable, the Court dismissed the possibility that the civil penalties might be "incidental to or intertwined with" the equitable remedy of injunctive relief. ${ }^{95}$ The Court pointed first to the large disparity between the size of the two forms of relief sought and concluded that a potential penalty of $\$ 22$ million "can hardly be considered incidental to the modest equitable relief sought in this case." the independence of the two forms of relief, emphasizing that the government was free to seek an equitable remedy in addition to, or independent of, legal relief. ${ }^{97}$ In other words, the remedy provision of the CWA does not itself intertwine equitable relief with the imposition of civil penalties, but rather separately authorizes each

so Id at $472-73$.

so Id at 470 .

91 Terry, $110 \mathrm{~S} \mathrm{Ct}$ at 1348.

92 Id.

os 481 US 412 (1987).

94 Clean Water Act, 65 Stat 1155, codified as amended at 33 USC § 1251 et seq (1988 \& Supp 1990) (injunctive relief may involve restoring waters damaged by pollution to their pre-polluted state).

${ }^{95}$ Tull, 481 US at 424.

98 Id at 424-25. The lower court assessed $\$ 325,000$ in fines against Tull and issued an injunction requiring Tull to clean up the properties. Id at 415-16.

${ }^{97}$ Id at 425. 
kind of relief. ${ }^{98}$ In such cases, said the Court, if a legal claim is joined with an equitable claim, the right to jury trial on the legal claim, including all issues common to both claims, remains intact. The right "cannot be abridged by characterizing the legal claim as incidental to the equitable relief sought."

Although Dairy Queen and Beacon Theatres remain good law, Tull seems to raise the possibility of incidental legal claims. However, the front pay award does not resemble the incidental legal claims set forth in Tull or in earlier cases. First, front pay is not incidental to reinstatement because the two remedies are independent. A plaintiff may seek front pay without seeking reinstatement, and may seek reinstatement without seeking front pay. ${ }^{100}$ Second, there can be a huge disparity in the size of the remedies. Reinstatement, in some cases, may have little value to a plaintiff who has just sued his employer, and studies have shown that the remedy rarely works in practice. ${ }^{101}$ Front pay awards, on the other hand, can be quite large, even when reduced to account for amounts the plaintiff would reasonably be able to earn in subsequent employment. ${ }^{102}$ Thus, monetary damages are often the only remedies of any great value to a victim of discrimination. Because of this large disparity in the value of reinstatement and front pay, and because the two forms of relief are independent, front pay would not qualify as an incidental legal claim under the Tull test.

c) Remedies "in lieu of" equitable remedies. In Deloach $v$ Delchamps, Inc., the Fifth Circuit concluded that front pay was an equitable remedy because reinstatement is an equitable remedy and front pay is awarded in lieu of reinstatement. ${ }^{103}$ However, front pay is awarded "in lieu of reinstatement" only in the sense that it is an alternative way of compensating for the same harm. An employee wrongfully ousted from his job has been deprived of the opportunity to earn wages from that job: he can either get his

${ }^{* 3}$ Id. See 33 USC $\S \S 1319(b), 1319$ (d).

90 Tull, 481 US at 425, citing Curtis, 415 US at $196 \mathrm{n} 11$.

${ }^{100}$ See Maxfield, 766 F2d at 793; Prudential Federal, 763 F2d at 173 n 2; Koyen $v$ Consolidated Edison Co. of New York, Inc., 560 F Supp 1161, 1169 (S D NY 1983).

${ }^{101}$ A survey conducted between 1973 and 1980 found that out of 217 employees who had been granted reinstatement, 114 employees (or 52.5\%) refused reinstatement, in part for fear of company backlash. Of those who accepted reinstatement, $87 \%$ left their positions within one year, with most leaving because of unfair company treatment. See Warren M. Chaney, The Reinstatement Remedy Revisited, 32 Labor L J 357, 359 (1981).

${ }^{102}$ In Dominic, 822 F2d at 1253 , the jury awarded the plaintiff $\$ 67,902$ in back pay and $\$ 378,000$ in front pay.

${ }^{103} 897$ F2d 815, 824 (5th Cir 1990). 
job back, or he can be awarded a sum of money representing his loss. The monetary damage award does not lose its presumptively "legal" status merely because it is offered in lieu of an equitable remedy.

The common law contains many examples in which legal monetary judgments are offered in lieu of equitable remedies. In contracts for the purchase of unique goods, for example, a plaintiff may seek either the equitable remedy of specific performance or monetary damages in lieu of specific performance. ${ }^{104}$ Similarly, in a tort law nuisance suit, a plaintiff may seek an injunction or monetary damages in lieu of an injunction. ${ }^{105}$

Such "alternative" remedies have always been available. Monetary damages do not become equitable remedies merely because they are offered in lieu of specific performance. ${ }^{108}$ In Willing $v$ Mazzocone, ${ }^{107}$ for example, the lower court had enjoined the defendant from making defamatory statements. The Pennsylvania Supreme Court reversed, stating that the legal remedy of monetary damages should have been awarded in lieu of the equitable remedy of an injunction, partly because the legal remedy preserved the plaintiff's jury trial rights. ${ }^{108}$ The fact that the monetary damages were to be awarded in lieu of an injunction did not convert the damages award into an equitable remedy.

\section{Pragmatic Considerations}

This Section examines the practical effects of having the jury determine the amount of the front pay award. First, considerations of judicial economy suggest that when allocating factfinding responsibilities between the judge and jury it makes sense to avoid duplication of effort. The factors involved in determining liability often parallel those involved in determining the amount of the damage award. It is inefficient to have both the judge and the jury consider these factors. ${ }^{108}$ Nor is the calculation of front pay awards a matter of such complexity as to suggest that a jury would be unable reasonably to determine them. This Section concludes that

${ }^{104}$ Dobbs, Handbook of the Law of Remedies $\S 12.1$ at 787, 796 (cited in note 57).

105 Id § 5.4 at 335 .

108 Id $\S 2.7$ at $83-85, \S 2.6$ at 70 .

$107482 \mathrm{~Pa} 377,393 \mathrm{~A} 2 \mathrm{~d} 1155$ (1978).

$108393 \mathrm{~A} 2 \mathrm{~d}$ at 1158.

${ }^{108}$ Another strong argument may be the consistency of judgments. If one decisionmaker is to determine liability and another the award, problems of inconsistency may arise. See Dominic, 822 F2d at 1257. 
pragmatic considerations support having the jury determine the amount of front pay.

\section{A. Judicial Economy, Expense, and Delay}

It is generally agreed that jury trials are more time-consuming $^{110}$ and expensive ${ }^{111}$ than bench trials. For each additional issue brought before the jury, the jury must spend additional time in deliberation and the court must spend time preparing jury instructions. The instructions themselves may become a source of contention among the litigants, perhaps engendering further litigation.

Although these are valid concerns, they are not relevant to the front pay issue because there is a significant overlap between the components of front pay and back pay awards. In calculating the size of a front pay award, the most important factor is generally the plaintiff's ability to mitigate future damages. At the point in the proceedings when front pay becomes an issue, the jury will have already examined the reasonableness of the employee's efforts to mitigate damages between the discharge and the trial in calculating the amount of the back pay award..12 In so doing, the jury will have already evaluated the relevant labor market conditions. ${ }^{113}$ Under these circumstances, it is practical and sensible that the jury also determine future mitigation relevant to a front pay award. Thus, to the extent that there is overlap with back pay, having the jury determine front pay will result in an even more efficient decision making process.

\section{B. Complexity of the Factfinding}

Another objection to having the jury calculate the front pay award is the belief that a jury should not determine complex fac-

110 The Chicago Jury Project Study estimated that jury trials are 40 percent more time consuming than bench trials. See Hans Zeisel, Harry Kalven, and Bernard Buchholz, Delay in the Court (Little, Brown, 1959), reprinted as Delay and the Jury in Charles W. Joiner, Civil Justice and the Jury 222, 230-31 (Prentice-Hall, 1962).

11 See Armster v United States District Court, 792 F2d 1423, 1425-30 (9th Cir 1986) (discussing Administrative Office of the United States's order suspending civil jury trials in the federal district courts for several months based partly on reduced congressional appropriations of funds for jury expenses).

112 Jackson v Shell Oil Co., 702 F2d 197, 202 (9th Cir 1983).

113 See, for example, Coleman $v$ City of Omaha, 714 F2d 804, 808 (8th Cir 1983) (To prove that plaintiff failed to mitigate damages, defendant had "to show that the plaintiff failed to use reasonable care and diligence and that there were jobs available which the plaintiff could have discovered and for which the plaintiff was qualified"); Coates $v \mathrm{Na}$ tional Cash Register Co., 433 F Supp 655, 662 (W D Va 1977) ("[U]nder the ADEA, an award for backpay [sic] must be reduced by an amount which the plaintiff could have earned had he sought alternative employment with 'reasonable diligence.' "). 
tual issues. ${ }^{114}$ However, attempts to strike down a trial by jury on this basis have seldom met with success. Juries have historically been, and continue to be, called upon to make delicate assessments such as calculating the damages for personal injury cases and estimating damages for pain and suffering. ${ }^{115}$ Juries decide damages in highly complex antitrust cases and play the role of factfinder in such complex areas of the law as securities litigation, medical malpractice, products liability, and commercial transactions. ${ }^{116}$ Despite commentators' substantial skepticism as to the wisdom of entrusting juries with these often monumental tasks, ${ }^{117}$ courts have seldom removed cases from the jury on this ground. ${ }^{118}$

More importantly, the factors involved in calculating front pay are not beyond the capabilities of the average layperson. In a typical front pay case, the court will instruct the jury to take into account testimony about the plaintiff's health, her life expectancy, her work expectancy, the availability of employment opportunities,

114 This, in fact, used to be one factor courts would consider when determining whether the Seventh Amendment compelled a right to a jury trial. See Ross, 396 US at 538 n 10. ("[T]he 'legal' nature of an issue is determined by considering ... the practical abilities and limitations of juries."). However, courts and commentators since Ross have refuted the notion that the complexity of the issue is part of the constitutional analysis. See, for example, Granfinanciera, 492 US at 42 (dropping complexity from the analysis). See also Redish, 70 Nw U L Rev at 526 (cited in note 72); Charles W. Wolfram, The Constitutional History of the Seventh Amendment, 57 Minn L Rev 639, 641 -42 (1973); Comment, Complex Litigation and the Seventh Amendment Right to a Jury Trial, 51 U Chi L Rev 581, 606-08 (1984); David M. Nocenti, Complex Jury Trials, Due Process, and the Doctrine of Unconstitutional Complexity, 18 Colum J L \& Soc Probs 1, 16-18 (1983); Comment, Beyond the Dicta: The Seventh Amendment Right to Trial by Jury Under Title VII, 38 U Kan L Rev 1003, 1012 (1990).

116 See McCormick, Handbook on the Law of Damages $\S 87$ at 311-12 (lost earnings in personal injury), $\S 88$ at 318 (pain and suffering) (cited in note 38). See also Borough $v$ Duluth, Missabe and Iron Range Ry. Co., 762 F2d 66, 69 (8th Cir 1985) ("calculation of damages [is a] question[] of fact and peculiarly within the province of the jury"); Herold $v$ Burlington Northern, Inc., 761 F2d 1241, 1248 (8th Cir 1985) ("The assessment of damages lies within the sound discretion of the jury.").

116 See In re U.S. Financial Securities Litigation, 609 F2d 411, 431 (9th Cir 1979).

127 See, for example, Note, The Right to Jury Trial in Complex Civil Litigation, 92 Harv L Rev 898, 906-11 (1979); Comment, The Right to an Incompetent Jury: Protracted Commercial Litigation and the Seventh Amendment, 10 Conn L Rev 775, 776-87 (1978); Comment, A More Rational Approach to Complex Civil Litigation in the Federal Courts: The Special Jury, 1990 U Chi Legal F 575, 576-78.

${ }_{218}$ But see In re Japanese Electronic Products Litigation, 631 F2d 1069, 1073-74, 1084-86 (3d Cir 1980) (court denied a jury trial in an antitrust case in which a nine-year discovery period had produced millions of documents, trial was expected to last one year, and jurors would have been required to analyze Japanese market conditions and business practices over a 30-year period and to make price comparisons of thousands of electronic products based upon their marketability, performance, and cost of production). 
the period within which the plaintiff by reasonable efforts should be re-employed, relevant labor market conditions, foreseeable layoffs, plant closures, and discount tables to determine the present value of future damages. ${ }^{119}$ These are the same considerations that govern awards of future damages in personal injury cases, where juries routinely determine the size of the award. ${ }^{\mathbf{1 2 0}}$ As the Third Circuit observed in Maxfield $v$ Sinclair Int'l, ADEA front pay awards are "no more speculative than awards for lost earning capability routinely made in personal injury and other types of cases." "121

Conversely, where Congress has unambiguously intended for the judge to assess a particular remedy, the courts are more willing to remove issues from the jury. In Tull, for example, the Supreme Court disallowed jury assessment of civil penalties even though it concluded that civil penalties were legal remedies. ${ }^{122}$ However, this was because the legislative history of the statute at issue, the Clean Water Act, ${ }^{123}$ made specific reference to judicial assessment of penalties. ${ }^{124}$ The Tull Court noted this, concluding that Congress had intended to assign this task to trial judges. ${ }^{125}$ Second, the Court appeared to be influenced by the criminal model of judicial sentencing, in which the jury determines culpability and the judge determines the punishment. ${ }^{126}$ Normally, this criminal model would be out of place in the civil law arena. Civil penalties, however, are uniquely situated: they are essentially fines for violating the law rather than compensatory damages. ${ }^{127}$ As such, they fall in the gap between the civil and criminal domains. It is not unreasonable to extend the criminal model to this unique situation in which laypersons may have trouble evaluating such factors as the seriousness of

\footnotetext{
119 See Fite, 861 F2d at 893 (discussing all these factors); Shore $v$ Federal Express Corp., 777 F2d 1155, 1160 (6th Cir 1985) (health and life expectancy); Koyen, 560 F Supp at 1169 (health and life expectancy, discounted to present value); Gibson, 695 F2d at 1100-01 and n 8 (work expectancy, layoffs and plant closures); Maxfield, 766 F2d at 797 (potential earnings, discounted to present value); Whittlesey, 742 F2d at 726 (potential earnings); Cleverly $v$ Western Electric Co., 450 F Supp 507, 511 (W D Mo 1978) (layoffs and plant closures).

2x0 See note 115 and accompanying text.

111766 F2d 788, 796 (3d Cir 1985).

122 Tull, 481 US at 423.

123 Clean Water Act, 33 USC § 1251 et seq.

124 Id at $\$ 1319$ (d).

123 Tull, 481 US at 425.

126 Id at 428 (Scalia dissenting).

${ }_{197}$ Dobbs, Handbook on the Law of Remedies $\S 3.1$ at 135, $\$ 3.9$ at 204-05 (cited in note 57).
} 
the violations. "A judge may be more qualified, consistent, and experienced" in making these types of calculations. ${ }^{128}$

The characteristics of civil penalties that make judicial assessment of them understandable are not present in the case of front pay. Unlike civil penalties under the CWA, front pay is awarded to compensate a plaintiff for harm, and the factors involved in calculating the remedy are designed to produce a damage award that accurately measures the extent of that harm. It is not an openended invitation for speculation as to the gravity of an employer's offense.

\section{ConCLUSION}

The legislative history of the ADEA indicates that Congress intended for the jury trial right to extend only to the factual issues surrounding a plaintiff's legal claims. When approached from almost every angle, the front pay remedy is a legal remedy. Historically, front pay was awarded to wrongfully terminated plaintiffs as a component of a lump sum compensatory damage award. Juries performed the calculations and determined the amount of the award. Moreover, the presumption that an award of monetary damages is a legal remedy still holds true today, and the Supreme Court has consistently stated that relief in the form of a money judgment is legal. Also, front pay does not have characteristics sufficient to convert it into an equitable remedy. Since front pay is compensatory in nature and does not contain elements of "unjust enrichment," it is not a form of restitution. Nor could front pay be considered equitable by virtue of being "incidental" to reinstatement, since the Supreme Court explicitly rejected the idea of incidental legal claims in Beacon Theatres and Dairy Queen. Even if one were to assume that Tull and Terry recognize that incidental legal claims still exist, front pay does not have the characteristics of an incidental legal claim as laid out in those decisions. In addition, although front pay is offered "in lieu of" reinstatement in the sense that reinstatement and front pay compensate for the same harm, it does not follow that front pay is therefore equitable. The legal nature of a remedy does not change merely because there exists equitable relief that compensates for the same harm. Front pay, then, is properly characterized as legal relief, and a jury trial right exists for the underlying factual issues and the amount of the

128 See Note, Right to Trial by Jury in an Action for Civil Penalties and Injunctive Relief Under the Clean Water Act, 28 Natural Resources J 607, 621 (1988). 
award. Jury assessment of the front pay award is also supported by pragmatic considerations since there is a significant factual overlap between front pay and back pay awards. 
